\title{
The millipede genus Trachysphaera Heller, 1858 in the Ukraine (Diplopoda: Glomeridae)
}

\author{
Авупарноногие многоножкки рода Trachysphaera Heller, 1858 \\ на Украине (Diplopoda: Glomeridae)
}

\author{
S.I. Golovatch \\ С.И. Головач
}

Institute for Problems of Ecology and Evolution, Russian Academy of Sciences, Leninsky prospekt 33, Moscow 119071 Russia. Институт проблем экологии и эволюции РАН, Ленинский проспект, 33, Москва 119071 Россия.

KEY WORDS: Diplopoda, Trachysphaera, Ukraine.

КЛЮЧЕВЫЕ СЛОВА: Diplopoda, Trachysphaera, Украина.

ABSTRACT. Three species of Trachysphaera occur in the Ukraine, all keyed and illustrated: T. costata (Waga, 1857) (largely parthenogenetic, bisexual only in a cave in the Crimea), T. acutula (Latzel, 1884) (restricted to the Carpathians and adjacent parts) and T. gibbula (Latzel, 1884) (represented by the easternmost isolate in a forest park near the city of Lvov).

РЕЗЮМЕ. На Украине обитают три вида Trachysphaera, и для всех трех приведены ключ и иллюстрации: T. costata (Waga, 1857) (в основном партеногенетические популяции, только в пещере в Крыму обоеполая), T. acutula (Latzel, 1884) (вид приурочен к Карпатам и прилежащим территориям) и T. gibbula (Latzel, 1884) (вид представлен самым восточным изолятом в лесопарке близ города Львова).

The Euro-Mediterranean millipede genus Trachysphaera Heller, 1858 contains over 30 species [Mauriès, 2006], of which only three have hitherto been reported from the Ukraine. Of them, T. costata (Waga, 1857 ) is known from solely parthenogenetic populations which occur in Central and Eastern Europe (Germany, Austria, Poland, Lithuania, Czech Republic, Slovakia, Hungary, much of Romania and some extra-Carpathian regions of the Ukraine), as well as some areas in the Caucasus, while bisexual populations are restricted to southern Romania, the Balkans, Anatolia, ?Israel, most of the Caucasus, and the Crimea [Golovatch, 1990, 2008; Gruber, 2009]. In the Ukraine, $T$. costata has been recorded as obligate parthenogenetic in the Carpathians and adjacent parts (Zakarpatye, Lvov, Ivano-Frankovsk, Ternopol, Chernovtsy and Odessa regions) [Chornyi \& Golovatch, 1993], as well as a bisexual population from a cave in the Crimea [Golovatch, 2008]. The second species, T. acutula (Latzel, 1884), is a basically Carpathian congener also known from Poland, Slovakia, Hungary and Romania (www.faunaeur.org). The presence, and even the status, of a third species in the fauna of the Ukraine, T. gibbula (Latzel, 1884], has remained questioned [Chornyi \& Golovatch, 1993; Golovatch, 2008].

Sverlova [1996] has rather recently reported on remarkable individual variation in pygidium shape in what she identified as a parthenogenetic population of T. costata from Rostochye, environs of Lvov, currently western Ukraine. This variation was first discovered there by Jawłowski [1929] who, based on the presence of a central projection on the pygidium in the two females he had, attributed the Rostochye sample to $T$. gibbula (Latzel, 1884), a basically Alpine species characterized by a distinct pygidial hump. Later, however, Jawłowski [1936, 1939] dropped $T$. gibbula altogether from the Polish list. Stojałowska [1961] confused the situation in following Jawłowski $[1936,1939]$ and referring to $T$. gibbula as a species absent from Poland, but, evidently after Jawłowski [1929], present in the Ukrainian part of Rostochye. Again based on material from Rostochye, this time coming from the Polish part of this transborder woodland area, Bielak-Oleksy et al. [1970], apparently again relying on the pygidial hump in some samples, found both $T$. costata and $T$. gibbula coexisting there. Sympatry of both was also documented using material from the nearby Bieszczady Mountains of Poland [Jaśkiewicz, 1978; Jędryczkowski, 1979]. Stojałowska \& Staręga [1974] referred to $T$. gibbula as a rare species which is currently known, besides Poland, only in Austria, Hungary, Croatia, Czech Republic and the Ukraine (www.faunaeur.org). Chornyi \& Golovatch [1993] followed Jawłowski [1929] in listing T. gibbula as possibly occurring in the Ukraine only in the vicinity of Lvov, but, following Jawłowski [1936, 1939], questioned the identity of this species. 

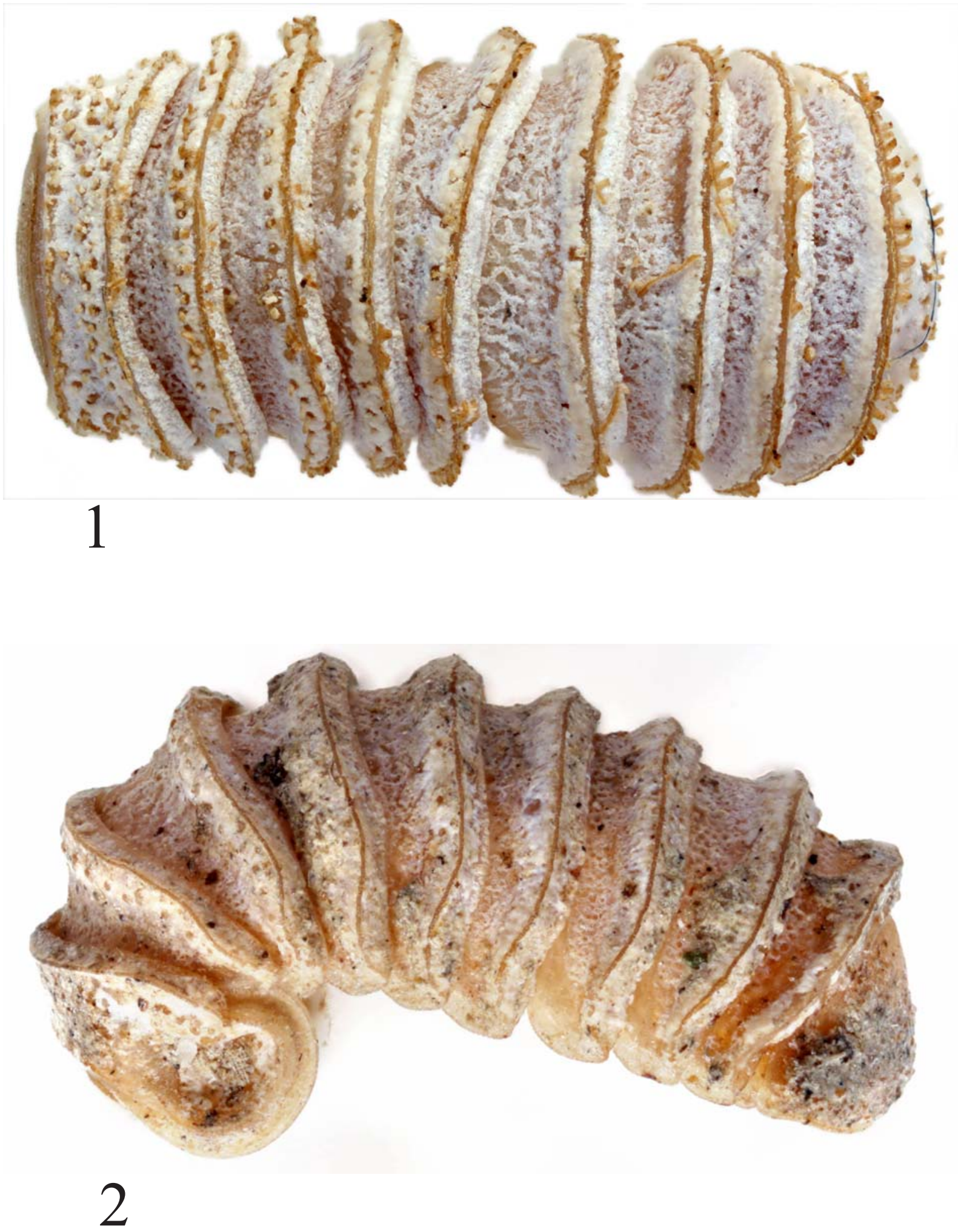

Figs 1 \& 2. Trachysphaera acutula, ,† from Skole, dorsal and lateral views, respectively.

Рис. 1 и 2. Trachysphaera acutula, ㅇ из Сколе, соответственно сверху и сбоку. 

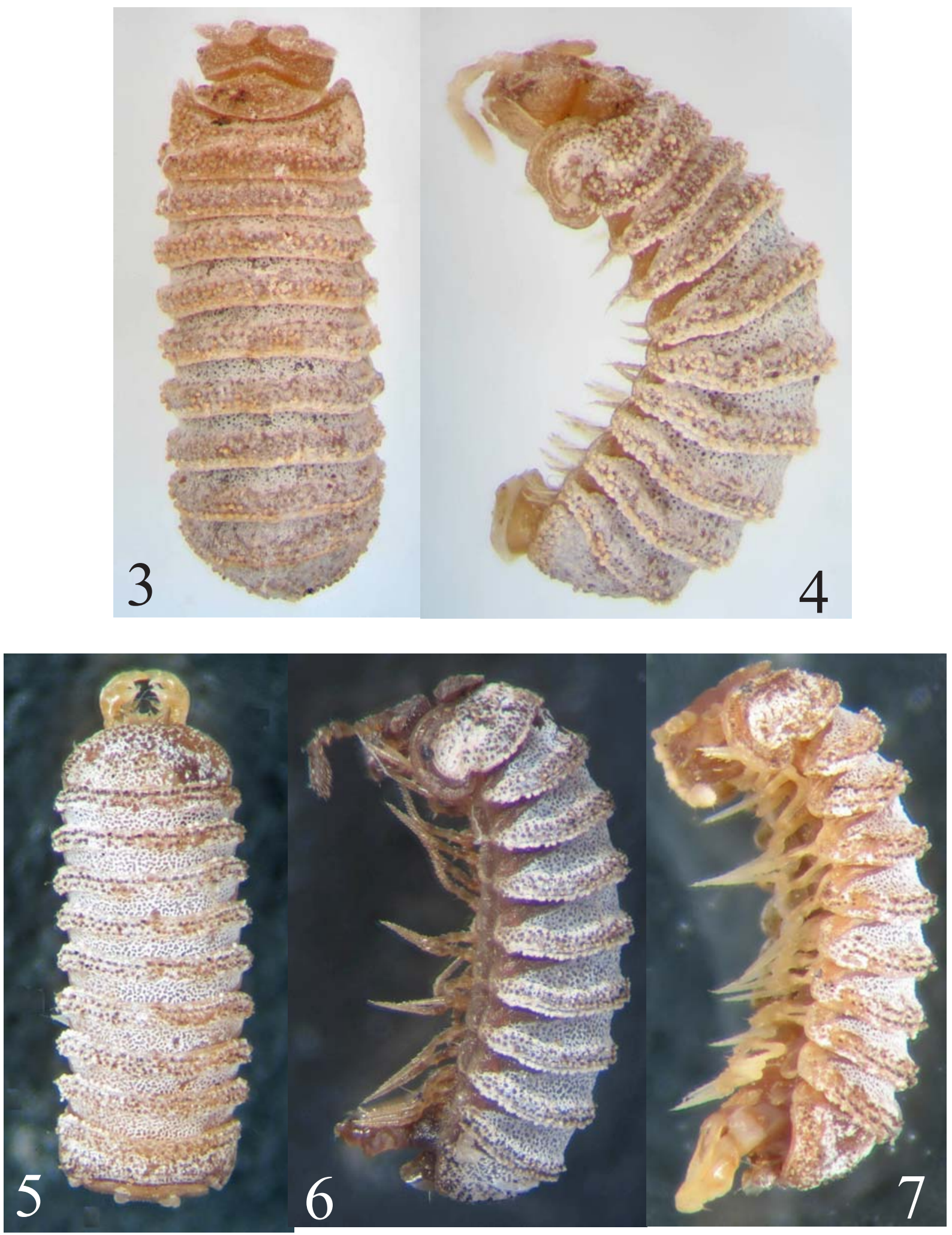

Figs 3-7. Trachysphaera costata, 9 from Rostochye Nature Reserve ( $3 \& 4$ ) and $0^{7} \bigcirc^{7}$ from Cave Mangupskaya, Crimea (5-7), dorsal, lateral, dorsal, lateral and lateral views, respectively.

Рис. 3-7. Trachysphaera costata, 9 из заповедника Росточье (3 и 4) и $0^{7} 0^{7}$ из Мангупской пещеры (Крым), соответственно сверху, сбоку, сверху, сбоку и сбоку. 

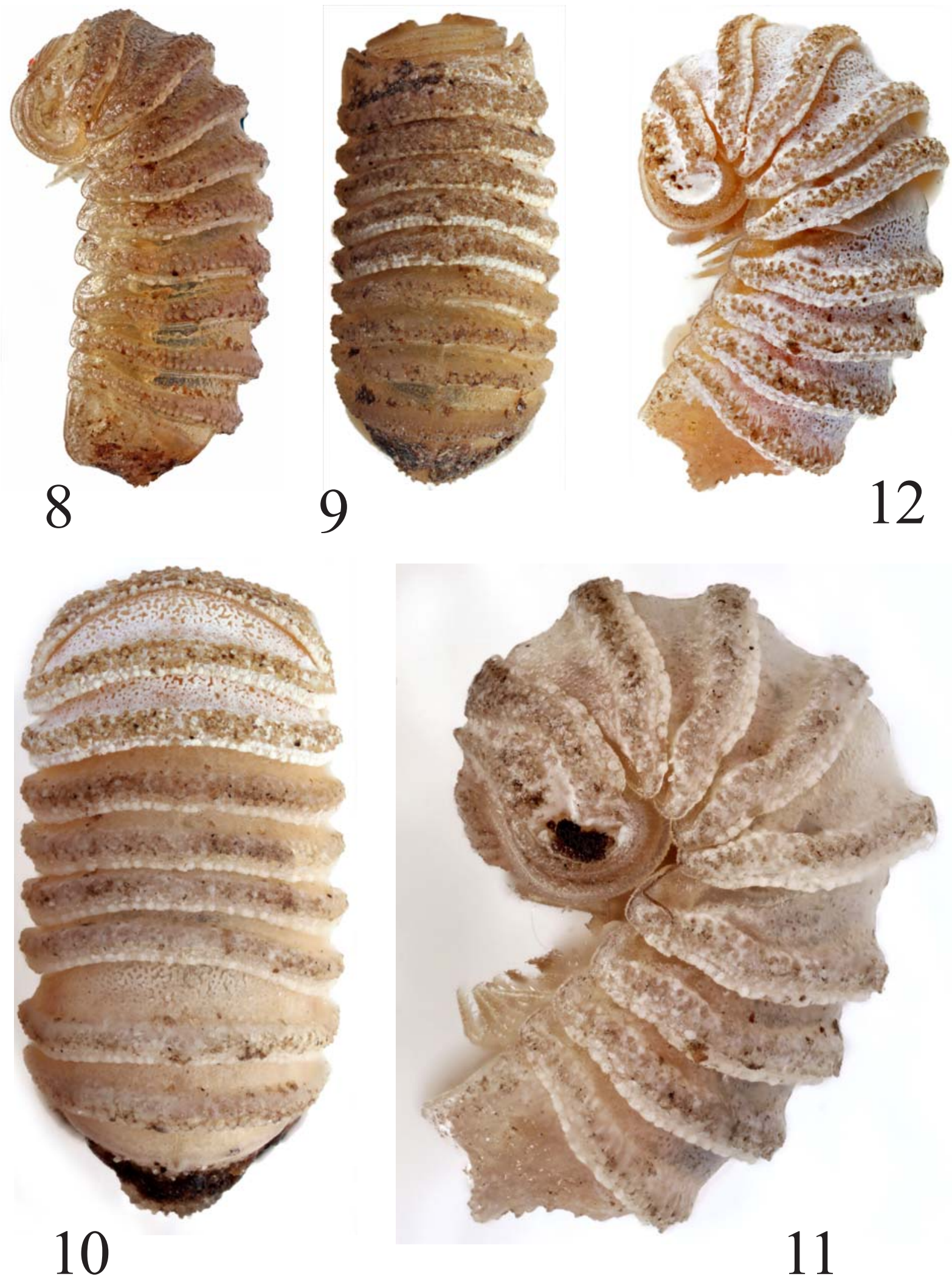

Figs 8-12. Trachysphaera gibbula, $ᄋ(8 \& 9)$ and $0^{7} 0^{7}(10-12)$ from Chortova Skala, dorsal, lateral, dorsal, lateral and lateral views, respectively.

Рис. 8-12. Trachysphaera gibbula,, ( $8 \&$ 9) и O$^{7}{ }^{\top}(10-12)$ из-под Чертовой скалы, соответственно сверху, сбоку, сверху, сбоку и сбоку. 
I have recently been privileged to re-examine the pertinent material referred to by Sverlova [1996] as belonging to $T$. costata. This has allowed me not only to clarify the identity of $T$. gibbula, but also prompted to compile and publish the present note. As a result, this material contains T. acutula: $4 \bigcirc^{7} \sigma^{7}, 10$ 우 from Lvov Region, Skole, Fagus, Carpinus \& Picea forest, 26.VII.1993, leg. N. Sverlova; and T. gibbula: $17 \bigcirc^{7} \sigma^{7}$, 18 ㅇ from the vicinity of Lvov, Vinniki Forest Park, near Chortova Skala (a limestone outcrop), 27.IV.1994, leg. N. Sverlova. Considering a sample of 4 우 of $T$. costata from the Rostochye Nature Reserve, Lvov Region, as well as another sample of the same species from Cave Mangupskaya, Crimea, both these samples referred to elsewhere [Golovatch, 2008], the Ukraine supports three Trachysphaera species which can be distinguished using the following key.

1. Transverse tergal crests lower (Figs 3-12), containing at least two, often three to four rows of short bacilli or grains . .. 2

- Transverse tergal crests higher (Figs 1 \& 2), mostly containing a single row of higher bacilli T. acutula

2. Pygidium with a more $\left(\sigma^{7}\right)$ or less $(+)$ prominent caudal tubercle centrally (Figs 8-12) ..................... T. gibbula

- Pygidium without evident tubercles (Figs 3-7) T. costata

ACKNOWLEDGEMENTS. My sincere thanks go to Nina Gural-Sverlova (Lvov, Ukraine) for sending me her samples for restudy, and for donating them entirely to the collection of the Zoological Museum, State University of Moscow, Russia. Jürgen Gruber (Vienna, Austria) kindly shared with me his opinion on the identity of these samples. Kirill Makarov (Moscow, Russia) skillfully took the photographs.

\section{References}

Bielak-Oleksy T., Jaśkiewicz W., Stojałowska W. 1970. Krocionogi (Diplopoda) Roztocza // Annales Universitatis Mariae Curie-Sklodowska Lublin. T.25(23). S.283-301.

Chornyi N.G., Golovatch S.I. 1993. [Millipedes of the Ukraine's Plain Territories]. Kiev. 58 pp. [in Russian, English summary].

Golovatch S.I. 1990. Diplopoda of the Caucasus, 3. Trachysphaeridae, with contributions to the fauna of Turkey // Senckenbergiana biologica. Bd.70. H.4/6. P.331-358.

Golovatch S.I. 2008. On three remarkable millipedes (Diplopoda) from the Crimea, Ukraine // International Journal of Myriapodology. Vol.1. P.97-110.

Gruber J. 2009. Zur Verbreitung von Trachysphaera costata (Waga, 1857) in Niederösterreich - eine für Österreichs Fauna neue Diplopodenart (Diplopoda: Glomerida: Doderiidae) // Contributions to Natural History. Vol.12. P.565-583.

Jaśkiewicz W. 1978. Nowe stanowiska rzadko notowanych w Polsce gatunkow Diplopoda // Folia Societatis Scientiarum Lublinensis, Biologia. T.10. S.55-60.

Jawłowski H. 1929. Krocionogi okolic Warszawy i niektore gatunki z innych miejscowości Polski // Sprawozdanie Komisji Fizjograficznej Polskiej Akademji Umiejętności. T.63. S.283314 .

Jawłowski H. 1936. Krocionogi poludniowo-wschodniej Polski // Fragmenta Faunistica Musei Zoologici Polonici. T.2 (25). S.253-298.

Jawłowski H. 1939. Verzeichnis der bisher bekannten DiplopodenArten Polens // Ibid. T.4 (10). S.211-219.

Jędryczkowski W. 1979. Krocionogi (Diplopoda) Bieszczadow // Fragmenta Faunistica. T.25 (6). S.77-94

Mauriès J.-P. 2006. Essai de classification des Glomerida (Diplopoda), et description de deux nouveaux genres du nord-ouest de la péninsule ibérique // Arthropoda Selecta. Vol.14 (for 2005). No.3. P.241-249.

Stojałowska W. 1961. Krocionogi (Diplopoda) Polski. Warszawa: PWN. 216 pp.

Stojałowska W., Staręga W. 1974. Krocionogi Diplopoda // Kata$\log$ fauny Polski. Warszawa, PWN. Cz.14. Z.2. 71 S.

Sverlova N.V. 1996. [Pygidial segment variation in a Trachysphaera costata (Diplopoda, Glomeridae) population from the vicinity of Lvov] // Vestnik zoologii (Kiev). T.30. S.75-76 [in Russian, English abstract]. 